\title{
Peran Badan Amil Zakat Nasional Kota Banjarmasin dalam Peningkatan Perekonomian Masyarakat
}

\author{
Taufiq Hidayat \\ Universitas Muhammadiyah Banjarmasin \\ taufiqhidayat120886@gmail.com
}

\begin{abstract}
Abstrack
The potency of tithe (locally called as zakat) recently is not optimally developed an professionaly managed. Ineffectiveness of operational of tithe collecting agency related to the aspects of administration, distributing, monitoring or in evaluating the tithe has become the factor of this condition. In other word, it can be assumed that the organizational system and management of tithe is still classical, consumptive and lacking of significant social impact. Bassed on that assumption, the role of government is demmed essential in coping with the issue. Through the tithe collecting agency either in local or in national level, it is espected the management of tithe collection can be optimally down. Meanwhile, Baznas in Banjarmasin City is the object of this reseach in which, according to the writer, this institution has played its rule quite well in the attempt of realizing the laws about the management of tithe (zakat) both in collecting, distributing, and using the tithe and in the attempt of developing the people economic through the prorams of Revolving Loan Fund given by Baznas of Banjarmasin City that can influence the development of the Mustahiq economic trough it recently is not fulfilled maximally.
\end{abstract}

Keywords: Roles, Baznas, Economic and Mustahiq

\section{Latar Belakang}

Islam adalah agama yang peduli terhadap masalah kemiskinan dan usaha peningkatan kualitas hidup. Untuk itu Islam menganjurkan umatnya untuk selalu berusaha dan bekerja keras. Anjuran ini bersifat individual maupun kolektif. Individual karena setiap individu dianjurkan untuk dapat hidup sejahtera. Kerja keras secara individu dilakukan dalam rangka mencapai kebahagiaan hidup sendiri dan keluarga. Sedangkan secara kolektif, umat Islam diharuskan bekerja dan berusaha untuk membantu sesama yang masih miskin atau kurang mampu. Kerja kolektif ini dilakukan dalam kerangka tanggung jawab sosial. ${ }^{1}$

\footnotetext{
${ }^{1}$ Muhamad Ridwan, Manajemen Baitul Maal wat-Tamwil. Yogyakarta: UII Press, 2004, 108.
} 
Zakat merupakan suatu kewajiban bagi umat Islam berdasarkan ketetapan dalam al-Qur'an, Sunah Nabi, dan Ijma' para ulama. ${ }^{2}$ Zakat merupakan suatu konsep ajaran Islam yang berdasarkan Al Qur'an dan Sunnah Rasul bahwa kita seseorang adalah amanat dari Allah dan berfungsi sosial. ${ }^{3}$ Zakat diwajibkan bagi para Aghniya' (hartawan) yang kekayaannya memenuhi batas minimal (nishab) untuk setahun (haul). ${ }^{4}$ Zakat bukan sekedar tanda kemurahan hati terhadap si miskin. ${ }^{5}$ Akan tetapi juga diharapkan dapat meminimalisir kesenjangan pendapatan antara si kaya dan si miskin. Disamping itu, Zakat juga diharapkan dapat meningkatkan dan menumbuhkan perekonomian baik pada level individu maupun pada level sosial masyarakat. ${ }^{6}$

Maka dengan adanya zakat merupakan solusi yang tepat untuk mewujudkannya. Tujuannya adalah menjadikan perbedaan ekonomi diantara masyarakat secara adil dan seksama, sehingga yang kaya tidak semakin kaya (dengan tidak memperdulikan masyarakat yang miskin), dan yang miskin tidak semakin miskin. Zakat merupakan bukti pernyataan rasa kemanusiaan dan keadaan persaudaraan Islam, pengikat persaudaraan umat dan bangsa, dan sebagai penghubung antara golongan kaya dan golongan miskin. ${ }^{7}$ Dengan adanya zakat akan terciptakan tatanan masyarakat yang sejahtera, dimana hubungan seorang dengan orang lain rukun dan damai.

Pelaksanan zakat diberikan melalui lembaga amil zakat didasarkan pada beberapa pertimbangan: Pertama, untuk menjamin kepastian dan disiplin zakat. Sebaliknya jika pelaksanaan zakat itu diberikan oleh muzaki sendiri, maka nasib dan hak-hak orang miskin dan para mustahiq lainnya terhadap orang-orang kaya tidak memperoleh jaminan yang pasti. Kedua, menjaga perasaan rendah diri para mustahiq apabila berhadapan langsung untuk menerima haknya dari para muzaki. Ketiga, untuk mencapai kecakapan, keakuratan dan sasaran yang tepat dalam penggunaan harta zakat menurut skala prioritas. Keempat, untuk

2 Abdul al-Hamid Mahmud al-Ba'ly, Ekonomi Zakat Sebuah Kajian Moneter dan Keuangan Syari'ah. Jakarta: PT Raja Grafindo Persada, 2006, 1.

${ }^{3}$ Sofyan Hasan, Pengantar Hukum Zakat dan Wakaf. Surabaya: Al-Ikhlas, 1995. 22.

${ }^{4}$ A. Rofiq, Fiqh Kontekstual dari Normatif ke Pemaknaan Sosial. Yogyakarta: Pustaka Pelajar, 2004, 261.

${ }^{5}$ Saefudin Zuhri, Zakat Kontekstual. Semarang; Bina Sakti, 2000, 9.

${ }^{6}$ Nuruddin Mhd. Ali, Zakat sebagai Instrumen dalam Kebijakan Fiskal. Jakarta: Raja Grafindo Persada, 2006, 2.

7 Adel Sarea, "Zakat as a Benchmark to Evaluate Economic Growth: an Alternative", International Journal of Business andn Social Science, 3(18) Special Issue, 242. 
memperlihatkan syiar Islam dan semangat penyelenggaraan negara dan pemerintah yang Islami. ${ }^{8}$

Hasil dari pengumpulan zakat tersebut akan didayagunakan kepada mustahiq sesuai dengan ketentuan agama. Dan orang-orang yang boleh dan berhak menerima zakat terbagi dalam 8 (delapan) golongan, sebagaimana firman Allah SWT dalam surat at-Taubah ayat 60, ("Sesungguhnya zakat-zakat itu, hanyalah untuk orang-orang fakir, orang-orang miskin, pengurus-pengurus zakat, para mualaf yang dibujuk hatinya, untuk (memerdekakan) budak, orang-orang yang berhutang, untuk jalan Allah dan orang-orang yang sedang dalam perjalanan, sebagai suatu ketetapan yang diwajibkan Allah, dan Allah Maha Mengetahui lagi Maha Bijaksana" (QS. at-Taubah: 60). ${ }^{9}$

Zakat yang telah terkumpul harus disalurkan kepada para mustahiq sebagaimana tergambar dalam surat di atas. Dari ayat tersebut dapat dilihat bahwa dari delapan golongan yang berhak menerima zakat, yang pertamatama disebut adalah orang fakir dan orang miskin. ${ }^{10}$ Dari sini dapat ditarik kesimpulan bahwa perioritas zakat adalah untuk golongan fakir dan miskin.

Salah satu masalah yang dihadapi kaum fakir, miskin adalah ketidakmampuan mereka dalam mencukupi kebutuhan dasar hidupnya. Ketidakmampuan mencukupi kebutuhan pokok ini disebabkan karena kurangnya pendapatan mereka atau mereka tidak mempunyai pendapatan. Bagi yang tidak mempunyai penghasilan (pekerjaan) maka solusinya adalah dengan memberikan mereka lapangan pekerjaan. Sedangkan bagi yang pendapatannya kurang akan diberi tambahan modal.

Pemanfaaatan dana zakat yang dijabarkan dalam ajaran fiqih memberi petunjuk perlunya suatu kebijaksanaan dalam kecermatan, dimana perlu mempertimbangkan faktor-faktor pemerataan dan penyamanan pengguna zakat dari yang bersangkutan yang mengarahkan kepada peningkatan kesejahteraan dan kebebasannya dari kemelaratan. ${ }^{11}$ Bahwa seringkali kita jumpai di masyarakat tentang penyaluran zakat secara langsung kepada mereka yang membutuhkan (mustahik).

Pengelolaan dan pendistribusian zakat harus segera ditangani dengan baik dan perlu mendapatkan perhatian yang khusus dari para pemungut zakat sehingga para wajib zakat itu percaya dan yakin tentang

\footnotetext{
${ }^{8}$ M. Abdul Malik Ar-Rahman, Pustaka Cerdas Zakat. Jakarta: Lintas Pustaka, 2003, 122.

${ }_{9}^{9}$ Departemen Agama RI, Al-Quran dan Terjemahnya,.....,156.

10 Clarashinta Canggih; Khusnul Fikriyah (2017), "Potensi dan Realisasi Dana Zakat Indonesia", Jurnal al-'Uqud, 1(1), 245-247.

${ }^{11}$ Ali Yafie, Menggagas Figh Sosial, Bandung: Mizan, 1994, 236.
} 
penyaluran zakatnya, hal seperti ini sangat bergantung kepada manajemen (Badan Amil Zakat Nasional). Apakah zakat itu sudah terealisasi dengan baik ataukah tidak dan apabila tidak ditangani dengan cara yang benar sudah barang tentu akan terjadi ketidaksempurnaan dalam penyaluran. ${ }^{12}$

Menghadapi kenyataan ketidaksuksesan pengumpulan zakat dikalangan umat Islam dan juga pendayagunaannya, ada beberapa kemungkinan yang terjadi, diantaranya: Kemungkinan bahwa selama ini kurang menggunakan pendekatan atau metode yang tepat untuk memasyarakatkan ajaran zakat dikalangan masyarakat Islam yang berkewajiban membayar zakat. Kemungkinan pembagian zakat secara tradisional yang bersifat konsumtif tidak akan banyak membuahkan hasil. Dengan kata lain, masih sangat jauh dari usaha pengentasan kemiskinan. ${ }^{13}$

Badan Amil Zakat Nasional Kota Banjarmasin merupakan salah satu organisasi pemerintah sebagai badan resmi pengelola zakat yang keberadaannya diatur berdasarkan keputusan Menteri Agama Republik Indonesia nomor 373 tahun 2003 tentang pelaksanaan UU nomor 38 tahun 1999 Tentang Pengelolaan Zakat, serta adanya Peraturan Daerah Kota Banjarmasin Nomor 31 Tahun 2004 Tentang Pengelolaan Zakat.

Kantor Badan Amil Zakat Nasional Kota Banjarmasin bertempat di Komplek Masjid Agung Miftahul Ihsan jalan. Pangeran Antasari Banjarmasin, Badan Amil Zakat ini dibentuk dengan tujuan memberikan pelayanan kepada muzakki dalam mengeluarkan zakat, infaq, dan sedekah. Pelayanan ini dilakukan baik kepada instansi pemerintah melalui Unit Pelayanan Zakat (UPZ) yang telah terbentuk maupun pelayanan kepada perorangan maupun perusahaan-perusahaan swasta.

\section{Metode Penelitian}

Metode penelitian yang digunakan adalah penelitian lapangan (field research). Jenis penelitian ini dapat pula disebut sebagai penelitian empiris, yaitu penelitian yang data dan informasinya diperoleh dari kegiatan di kancah (lapangan) kerja penelitian. ${ }^{14}$ Dalam posisi penelitian kualitatif, maka posisi peneliti memegang kunci untuk menggali data. Dengan demikian, peran peneliti sangat menentukan dan memegang kendali data di lapangan sesuai asumsi yang dimiliki.

Penelitian ini dilakukan secara intensif, terperinci dan mendalam terhadap suatu objek tertentu dengan mempelajari sebagai suatu kasus dengan maksud untuk mecari kajian data empirik yang ditemukan

\footnotetext{
12 M. Ali Hasan, Perbandingan Madzhab Fiqh. Jakarta: PT. Raja Grafindo Persada, 2001, 116.

${ }^{13}$ A. Qodri Azizy, Membangun Fondasi Umat, Yogyakarta: Pustaka Pelajar, 2004, 135.

14 Supardi, Metodologi penelitian ekonomi dan bisnis. UII Press, Yogyakarta, 2005, 34.
} 
dilapangan yang dalam hal ini Badan Amil Zakat Kota Banjarmasin, untuk kemudian dianalisis secara deskriptif dengan rujukan bahan pustaka.

\section{Hasil Penelitian}

Sistem pendistribusian zakat di Badan Amil Zakat Nasional Kota Banjarmasin dibagi dalam dua bentuk yaitu konsumtif dan produktif (modal usaha). pendistribusian zakat secara konsumtif sebenarnya tidak akan banyak membuahkan hasil karena zakat akan habis dalam waktu singkat sehingga dana zakat tidak dapat berkembang, Sedangkan pendistribusian zakat secara produktif (modal usaha) selain dapat mengembangkan dana zakat, juga dapat melatih jiwa wirausaha atau dengan kata lain akan memunculkan jiwa kreatifitas mustahiq dalam mengembangkan usaha yang digelutinya sehingga dana zakat yang diberikan akan bergulir dengan tujuan bahwa seorang mustahiq nantinya akan bisa beralih menjadi seorang muzakki.

Sebagian besar dana yang dijatah untuk kategori konsumtif seharusnya dikurangi, sehingga anggaran untuk zakat produktif sedikit lebih banyak. Karena distribusi untuk konsumtif hanya bisa memenuhi kebutuhan sesaat, terkadang juga malah membuat ketergantungan para mustahiq terhadap dana zakat, sehingga mereka (mustahiq) tidak terdidik untuk berupaya mengembangkan diri dalam berusaha karena mereka hanya tinggal menunggu hasil tanpa ada usaha dari diri mereka sendiri. Tetapi apabila distribusi dana untuk zakat produktif lebih diperbanyak maka secara tidak langsung juga akan dapat membantu banyak para mustahiq untuk dapat berusaha mandiri sehingga bisa lepas dari kemiskinan dan bisa mengurangi angka pengangguran, selain itu juga mereka (mustahiq) dapat memenuhi kebutuhan hidup sendiri dan keluarganya. Karena dengan pemberian zakat secara produktif (modal usaha), maka zakat yang diberikan dapat bergulir dan dapat membantu dalam meningkatkan perekonomian mereka. Badan Amil Zakat Nasional Kota Banjarmasin juga harus lebih jeli dalam menyeleksi para mustahiq yang akan diberikan zakat baik secara konsumtif maupun produktif, tidak hanya berdasrkan laporan yang diserahkan ke Badan Amil Zakat Nasional Kota Banjarmasin saja, tetapi harus adanya dukungan data yang benar-benar nyata dilapangan.

Sebenarnya, Badan Amil Zakat Nasional Kota Banjarmasin dalam merumuskan praktek pemberian zakat produktif sebagai modal usaha sudah sesuai dengan prosedur dalam pendistribusian zakat untuk usaha produktif yang terdapat dalam Keputusan Menteri Agama Republik 
Indonesia No. 373 Tahun 2003 Tentang Pelaksanaan Undang-undang No. 38 Tahun 1999 Tentang Pengelolaan Zakat Pasal 29, yaitu:

1. melakukan studi kelayakan.

2. menetapkan jenis usaha produktif.

3. melakukan bimbingan dan penyuluhan.

4. melakukan pemantauan, pengendalian dan pengawasan.

5. mengadakan evaluasi.

6. membuat pelaporan. ${ }^{15}$

Menurut penulis jika Pasal 29 Keputusan Menteri Agama Republik Indonesia No. 373 Tahun 2003 Tentang Pelaksanaan Undang-undang No. 38 Tahun 1999 Tentang Pengelolaan Zakat tersebut dilaksanakan maka pelaksanaan usaha produktif dapat berjalan maksimal. Serta pelanggaranpelanggaran/penyelewengan dana zakat tidak akan terjadi atau bisa diminimalisir seperti halnya dana zakat yang seharusnya untuk modal usaha digunakan untuk membelanjakan kebutuhan sehari-hari, atau malah untuk membayar hutang. Karena dengan Keputusan Menteri Agama Republik Indonesia No. 373 Tahun 2003 pasal 29 tersebut ada ikatan yang mengikat antara pemberi modal (BAZNAS) dan penerima modal usaha (Mustahiq) berupa bimbingan, penyuluhan, pemantauan, pengendalian, pengawasan, evaluasi, dan pelaopran. Sehingga antara penerima bantuan modal dari dana zakat produktif dan pemberi modal, dalam hal ini Badan Amil Zakat Nasional Kota Banjarmasin masih ada ikatan dan berjalan bersama-sama untuk mewujudkan tercapainya usaha yang dilakukan oleh para mustahiq.

Pendistribusian zakat oleh Badan Amil Zakat Nasional Kota Banjarmasin sebagai modal usaha, menurut penulis juga perlu adanya program keterampilan bagi para mustahiq yang tepat dengan kemampuan bakat para mustahiq sebagai bekal para mustahiq dalam mengelola dana bantuan zakat sebagai modal usaha, Badan Amil Zakat Nasional Kota Banjarmasin bisa bekerjasama dengan Departemen-departemen dilingkungan Pemerintahan Kota Banjarmasin yang terkait, semisal Deprtemen Ketenaga Kerjaan, Usaha Kecil dan Menengah, atau bisa juga dengan mengundang para pengusaha-pengusaha yang telah berhasil dalam usahanya untuk memberikan bekal serta pengalaman berusaha mereka. Sehingga, ketika seorang mustahiq yang akan menerima bantuan modal usaha tidak bingung dalam penggunaannya. Karena dengan adanya pelatihan tersebut dapat menambah daya kreatifitas serta penumbuhan jiwa wirausaha dalam jiwa mustahiq. Dengan demikian

15 Pasal 29, Keputusan Menteri Agama RI Nomor 373 Tahun 2003 Tentang Pelaksanaan Undang-Undang Nomor 38 Tahun 1999 Tentang Pengelolaan Zakat. 
maka para mustahiq akan langsung bisa memanfaatkan dana yang telah diberikan oleh Badan Amil Zakat Nasional Kota Banjarmasin.

Tetapi dalam pelaksanaannya Badan Amil Zakat Nasional Kota Banjarmasin kurang maksimal dalam pendistribusian zakat untuk kategori produktif. Hal ini terbukti dalam pendistribusian untuk modal usaha belum terlihat hasilnya. Menurut penulis hal ini disebabkan selain karena manajemen didalam Badan Amil Zakat Nasional Kota Banjarmasin sendiri belum rapi juga dikarenakan kurangnya penanganan dan pembinaan untuk kategori produktif, karena sampai saat ini usaha-usaha yang dijalankan oleh mustahiq dari pemberian zakat belum mengalami perkembangan yang signifikan.

Selain memberikan pembinaan terhadap mustahiq, Badan Amil Zakat Nasional Kota Banjarmasin juga seharusnya selalu memonitor perkembangan usaha yang dijalankan oleh para mustahiq. Jadi nantinya akan diperoleh dimana tingkat efektifitas pemberian zakat sebagai modal usaha. Dimana Badan Amil Zakat Nasional Kota Banjarmasin dapat mengetahui segala sesuatu yang berkaitan dengan usaha yang dijalankan. Seperti halnya, kesulitan-kesulitan yang dialami oleh mustahiq dalam menjalankan usahannya. Sehingga Badan Amil Zakat Nasional Kota Banjarmasin dapat membantu mencarikan pemecahan terhadap persoalan-persoalan yang terjadi dilapangan.

Menurut penulis, bahwa selama ini mekanisme yang dilakukan oleh Badan Amil Zakat Nasional Kota Banjarmasin terhadap usaha para mustahiq yang mendapatkan dana hanya sebatas memberikan saja, belum adanya monitoring maupun pembinaan terhadap mustahiq. Sehingga Badan Amil Zakat Nasional Kota Banjarmasin tidak akan dapat memperoleh indikasi efektifitas dalam memberikan zakat sebagai modal usaha. Sehingga tingkat efektifitas dalam pemberian zakat produktif sebagai modal usaha yang dillaksanakan oleh Badan Amil Zakat Nasional Kota Banjarmasin selama ini belum tercapai secara maksimal. Masih perlu adanya pembenahan-pembenahan dalam praktek pemberian zakat produktif sebagai modal usaha oleh Badan Amil Zakat Nasional Kota Banjarmasin.

Berikut peneliti sajikan data penerima pinjaman modal dana bergulir UMKM Badan Amil Zakat Nasional Kota Banjarmasin Tahun 2012:16

${ }^{16}$ Sumber Data: Laporan Keuangan Pinjaman Modal Dana Bergulir UMKM Badan Amil Zakat Nasional Kota Banjarmasin Tahun 2012. 
Tabel 4.4

Data Penerima Pinjaman Modal Dana Bergulir UMKM

Badan Amil Zakat Nasional Kota Banjarmasin

Tahun 2012

\begin{tabular}{|c|c|c|c|c|}
\hline $\mathrm{NO}$ & NAMA & ALAMAT & $\begin{array}{l}\text { JENIS } \\
\text { USAHA }\end{array}$ & $\begin{array}{l}\text { JUMLAH } \\
\text { PINJAMAN }\end{array}$ \\
\hline 1 & M. Nasrullah & Jl. Kelayan & Dagang & Rp. 1.500 .000 \\
\hline 2 & Suriansyah & $\begin{array}{ll}\text { Jl. } & \text { S. } \\
\text { ParmanGg.Kalimantan }\end{array}$ & Jual Nasi & Rp. 3.000 .000 \\
\hline 3 & M. Khatib & Jl. S.Parman rt. 21 No. 4 & KiosPulsa & Rp. 3.000.000 \\
\hline 4 & Husni Nafrin & $\begin{array}{ll}\text { Jl. } & \text { S. } \\
\text { ParmanGg.Kalimantan }\end{array}$ & Minuman & Rp. 3.000 .000 \\
\hline 5 & Misnawati & Jl. Raga Buana & Makanan & Rp. 3.000.000 \\
\hline 6 & Ririn Indriani & Jl. Raga Buana & Jual Tas & Rp. 3.000 .000 \\
\hline 7 & Umi Salamah & Jl. Raga Samudera & Dagang & Rp. 2.000 .000 \\
\hline 8 & St. Raudah & Jl.A.YaniKm.6Banjarmasin & Sembako & Rp. 3.000 .000 \\
\hline 9 & Nurina & Jl. Kuin Selatan & KriditBaju & Rp. 2.000 .000 \\
\hline 10 & Nurdin & Jl. Kuin Selatan & Dagang & Rp. 2.000 .000 \\
\hline 11 & Agus Rifani & J1. Sutoyo S Gg. Warga & Dagang & Rp. 1.000 .000 \\
\hline 12 & Kamsiah & Jl. Kuin Utara & Dagang & Rp. 1.500 .000 \\
\hline 13 & Hernadi & Jl. Pulau Laut & Dagang & Rp. 1.000 .000 \\
\hline 14 & Satimin & Jl. Pulau Laut & Dagang & Rp. 1.000 .000 \\
\hline 15 & Fadlan & Jl. Kuin Utara & Dagang & Rp. 1.500 .000 \\
\hline 16 & Mastinah & J1. Sutoyo S & Dagang & Rp. 1.000 .000 \\
\hline 17 & Hj. Kartini & J1. Sutoyo S Gg. Warga & Dagang & Rp. 1.000 .000 \\
\hline 18 & PKBMAlHkmah & J1. Cemara Raya & Koperasi & Rp. 20.000 .000 \\
\hline 19 & Sahlani & Jl. Pekapuran Raya & Dagang & Rp. 2.500 .000 \\
\hline 20 & Jamilah & Jl. Pekapuran Raya & Sembako & Rp. 3.000 .000 \\
\hline 21 & Nursinah 1 & Jl. Pekapuran Raya & Klontongan & Rp. 2.500 .000 \\
\hline 22 & Herlina & Jl. Pekapuran Raya & Sembako & Rp. 3.000.000 \\
\hline 23 & Husni & Jl. Pekapuran Raya & Klontongan & Rp. 3.000.000 \\
\hline 24 & Mulkiah & Jl. Pekapuran Raya & Dagang & Rp. 2.500 .000 \\
\hline 25 & Sariati & Jl. Pekapuran Raya & Jual Nasi & Rp. 2.500.000 \\
\hline 26 & Rina & Jl. Pekapuran Raya & Kelontongan & Rp. 2.000.000 \\
\hline 27 & Tina & Jl. Pekapuran Raya & Dagang & Rp. 2.000 .000 \\
\hline 28 & Kiyah & Jl. Pekapuran Raya & Dagang & Rp. 2.500 .000 \\
\hline 29 & Ardiansyah & Jl. Pekapuran Raya & Dagang & Rp. 2.000 .000 \\
\hline 30 & Mariani KM & Jl. Pekapuran Raya & Dagang & Rp. 2.000 .000 \\
\hline 31 & Faisal Embrn & Jl. Pekapuran Raya & Dagang & Rp. 2.000 .000 \\
\hline
\end{tabular}




\begin{tabular}{|c|c|c|c|c|}
\hline 32 & Rabiatul A & Jl. Pekapuran Raya Rt. 18 & Dagang Es & Rp. 1.500 .000 \\
\hline 33 & Nursinah 2 & Jl. Pekapuran Raya Rt. 18 & Klontongan & Rp. 1.500 .000 \\
\hline 34 & Masitah & Jl. Pekapuran Raya & Dagang & Rp. 1.500 .000 \\
\hline 35 & Nur Salimah & Jl. Pekapuran Raya & Dagang & Rp. 1.500 .000 \\
\hline 36 & Lian Nor & Jl. Pekapuran Raya & Dagang & Rp. 1.500 .000 \\
\hline 37 & Maimunah & J1. Pekapuran Raya & Dagang & Rp. 1.500 .000 \\
\hline 38 & Hj. Saibah & Jl. Sutoyo S Rt. 17 No. 38 & Sembako & Rp. 4.000 .000 \\
\hline 39 & Noormaliyani & $\begin{array}{l}\text { Jl. Pekapuran } \\
\text { Rt.22No.39 }\end{array}$ & Sembako & Rp. 4.000 .000 \\
\hline 40 & Noermah & Jl. Pekapuran A No. 52 & Jual Telor & Rp. 3.000.000 \\
\hline 41 & Misbah Sauri & $\begin{array}{ll}\text { Jl. } & \text { Purnasakti } \\
\text { alurBlok.C.37 } & \\
\end{array}$ & Dagang & Rp. 2.500 .000 \\
\hline 42 & Rusmini & Jl. Gunung Sari X Rt.17 & Dagang & Rp. 2.500 .000 \\
\hline 43 & Sri Elis & Jl. Raga Buana III No. 147 & Jual Baju & Rp. 2.500 .000 \\
\hline 44 & Nurliany & Jl. Srikandi & Dagang Es & Rp. 1.500 .000 \\
\hline 45 & Hj. Hadijah & Pasar Cemara Ujung & Dagang & Rp. 2.500 .000 \\
\hline 46 & Syamsu A & Pasar Cemara Ujung & Penjahit & Rp. 2.500 .000 \\
\hline 47 & Aspihani & Pasar Cemara Ujung & Sendal & Rp. 2.000 .000 \\
\hline 48 & Mariati & Pasar Cemara Ujung & Dagang & Rp. 2.000 .000 \\
\hline 49 & Arbain & Pasar Cemara Ujung & Dagang & Rp. 2.000 .000 \\
\hline 50 & Selamat & Pasar Cemara Ujung & Dagang & Rp. 2.000.000 \\
\hline 51 & Ernawati & Pasar Cemara Ujung & Dagang & Rp. 2.000 .000 \\
\hline 52 & Siti Mulia & Pasar Cemara Ujung & Gorengan & Rp. 1.000 .000 \\
\hline 53 & M. Yusri & Jl. Arjuna Komp. Srikandi & Makanan & Rp. 1.000 .000 \\
\hline & JUMLAH & & & Rp.130.000.000 \\
\hline
\end{tabular}

Sumber Data: Laporan Keuangan Pinjaman Modal Dana Bergulir UMKM Badan Amil Zakat Nasional Kota Banjarmasin tahun 2012.

Dalam mengukur pengaruh pinjaman modal dana bergulir UMKM yang dilakukan oleh Badan Amil Zakat Nasional Kota Banjarmasin terhadap peningkatan perekonomian masyarakat (mustahiq), penulis hanya menggunakan cara yang sangat sederhana yaitu dengan melihat data-data mustahiq yang telah menerima bantuan zakat dari Badan Amil Zakat Nasional Kota Banjarmasin dan melihat kondisi para mustahiq setelah mendapatkan bantuan tersebut. Setelah melihat data-data yang ada lalu penulis mencoba menganalisa data sesuai dengan kondisi mustahiq. 
Dibawah ini penulis sajikan data mustahiq setelah mendapatkan pinjaman modal dana bergulir UMKM yang dilakukan oleh Badan Amil Zakat Nasional Kota Banjarmasin,

Tabel 4.5

Data mustahiq setelah mendapat bantuan zakat produktif dari Badan Amil Zakat Nasional Kota Banjarmasin

\begin{tabular}{|c|c|c|c|c|c|}
\hline \multirow[t]{2}{*}{ No } & \multirow[t]{2}{*}{ Nama } & \multirow[t]{2}{*}{ Jenis Usaha } & \multicolumn{3}{|c|}{$\begin{array}{l}\text { Kondisi Ekonomi } \begin{array}{r}\text { Setelah } \\
\text { Mendapat } \\
\text { Modantuan }\end{array} \text { Pinjaman } \\
\text { Modana Bergulir UMKM }\end{array}$} \\
\hline & & & Tetap & Membaik & Maju \\
\hline 1 & Suriansyah & Jual Nasi & & $\sqrt{ }$ & \\
\hline 2 & M. Khatib & KiosPulsa & & & $\sqrt{ }$ \\
\hline 3 & Husni Nafrin & Minuman & & $\sqrt{ }$ & \\
\hline 4 & Misnawati & Makanan & & $\sqrt{ }$ & \\
\hline 5 & Ririn Indriani & Jual Tas & & $\sqrt{ }$ & \\
\hline 6 & Nurliany & Pedagang Es & $\sqrt{ }$ & & \\
\hline 7 & Syamsu A & Penjahit & $\sqrt{ }$ & & \\
\hline 8 & Husni & Klontongan & & & $\sqrt{ }$ \\
\hline 9 & Siti Mulia & Gorengan & & $\sqrt{ }$ & \\
\hline 10 & Rabiatul A & Pedagang Es & $\sqrt{ }$ & & \\
\hline 11 & Sri Elis & Jual Baju & & $\sqrt{ }$ & \\
\hline 12 & Hj. Saibah & Sembako & & & $\sqrt{ }$ \\
\hline 13 & Sariati & Jual Nasi & $\sqrt{ }$ & & \\
\hline 14 & Jamilah & Sembako & & $\sqrt{ }$ & \\
\hline 15 & Aspihani & Penjual Sendal & $\sqrt{ }$ & & \\
\hline 16 & St. Raudah & Sembako & & $\sqrt{ }$ & \\
\hline 17 & Herlina & Sembako & & $\sqrt{ }$ & \\
\hline 18 & Nurina & Kridit Baju & & $\sqrt{ }$ & \\
\hline 19 & M. Yusri & Makanan & & $\sqrt{ }$ & \\
\hline 20 & Rina & Klontongan & & & $\sqrt{ }$ \\
\hline 21 & Nursinah & Klontongan & & & $\sqrt{ }$ \\
\hline 22 & Normaliyani & Sembako & & & $\sqrt{ }$ \\
\hline 23 & Noermah & Jual Telor & & & $\sqrt{ }$ \\
\hline
\end{tabular}

Dari data di atas, hampir semua kondisi ekonomi mustahiq setelah mendapat bantuan pinjaman modal dana bergulir UMKM dari Badan Amil Zakat Nasional Kota Banjarmasin membaik bahkan ada 7 mustahiq yang mengalami kemajuan dan hanya 5 orang saja yang kondisi ekonominya tetap. Jadi, distribusi zakat yang diberikan oleh Badan Amil 
Zakat Nasional Kota Banjarmasin kepada mustahiq bisa dikatakan mempengaruhi peningkatan perekonomian masyarakat (mustahiq)

\section{Kesimpulan}

Pendistribusian zakat yang dilakukan oleh Badan Amil Zakat Nasional Kota Banjarmasin melalui pinjaman modal dana bergulir UMKM dapat mempengaruhi peningkatan perekonomian mustahiq walaupun kurang maksimal. Hal ini dilatar belakangi pendidikan dan wawasan para mustahiq yang minim. Kurang optimalnya upaya "monitoring" dari Badan Amil Zakat Nasional Kota Banjarmasin terhadap mustahiq yang menerima zakat produktif (pinjaman modal dana bergulir UMKM), karena masih ada mustahiq yang kondisi kesejahteraannya masih tetap.

\section{Daftar Pustaka}

Adel Sarea, "Zakat as a Benchmark to Evaluate Economic Growth: an Alternative", International Journal of Business andn Social Science, 3(18) Special Issue.

Ali, Nuruddin Mhd. 2006. Zakat sebagai Instrumen dalam Kebijakan Fiskal. Jakarta: Raja Grafindo Persada

Ar Rahman, Syaikh Muhammad Abdul Malik. 2003. 1001 Masalah Dan Solusinya. Jakarta: Pustaka Cerdas Zakat.

Azizy, A. Qodri. 2004. membangun Fondasi Umat. Yogyakarta: Pustaka Pelajar.

Clarashinta Canggih; Khusnul Fikriyah (2017), "Potensi dan Realisasi Dana Zakat Indonesia”, Jurnal al-‘Uqud, 1(1).

Departemen Agama RI. 2005. Al-Quran dan Terjemahnya. Bandung: Diponegoro.

Hasan, M. Ali. 2001. Perbandingan Madzhab Fiqh. Jakarta: PT. Raja Grafindo Persada.

Keputusan Menteri Agama RI Nomor 373 Tahun 2003 Tentang Pelaksanaan Undang-Undang Nomor 38 Tahun 1999 Tentang Pengelolaan Zakat.

Laporan Keuangan Pinjaman Modal Dana Bergulir UMKM Badan Amil Zakat Nasional Kota Banjarmasin Tahun 2012. 
Mahmud, Abdul al-Hamid al-Ba'ly. 2006. Ekonomi Zakat Sebuah Kajian Moneter dan Keuangan Syari'ah. Jakarta: PT. Raja Grafindo Persada.

Ridwan Muhamad. 2004. Manajemen Baitul Maal wat-Tamwil. Yogyakarta: UII Press.

Rofiq, A. 2004. Fiqh Kontekstual dari Normatif ke Pemaknaan Sosial. Yogyakarta: Pustaka Pelajar.

Supardi. 2005. Metodologi penelitian ekonomi dan bisnis. Yogyakarta: UII Press.

Yafie, Ali. 1994. Menggagas Fiqh Sosial. Bandung: Mizan.

Zuhri, Saefudin. 2000. Zakat Kontekstual. Semarang; Bina Sakti. 